INTERNATIONAL HIGHER EDUCATION, Number 62 Winter 2011

Pages 20-21

International Education in Australia: A Long Way Down

Simon Marginson

Simon Marginson is professor of higher education at the University of Melbourne, Australia. E-mail: s.marginson@unimelb.edu.au.

In Australian universities, more than one in four students are full-fee-paying international students, and education is the nation's fourth-largest export sector after coal, iron ore, and gold. In the last two decades international students have grown by a remarkable 12 percent per annum. Australia enrolls almost as many students from China, including Hong Kong, as the United States.

Australia, a modest nation of 21 million people, commands 6 percent of the world market in international education. Its research universities have more than half as many foreign students as does the whole US doctoral sector, though the US population is 15 times larger than that of Australia. It is impressive or, to be strictly accurate, it was impressive. The Australian business model of international education has long been noted by other countries as a sign of the potential—and limits—of what educational marketing can achieve.

But if you live by the sword you die by the sword. When market forces rule, while business is booming everything looks sweet, but in the world of the market, boom is always followed by bust.

Australian international education is in trouble, and the downgrade is likely to be large and long. But this drop was not triggered by the subprime sector or 
the global financial crisis. Worldwide demand for international education is robust, driven by continuing high economic growth in Asia. The problem is of Australia's own making and is largely government-policy driven.

A sharp reduction in international enrollments in higher education is expected next year. This is a serious problem for universities, which receive an average 16 percent of all their income from this source. In some institutions the level of dependence is well over 20 percent.

The larger economic effects of the downturn in international education are just as important. International education employs more than 125,000 people in industries such as housing, retail, the health sector, insurance, travel, telecommunications and information technology, cinemas, and migration services. It is especially crucial to the economies of inner-urban Melbourne and Sydney and to certain regions.

\section{NUMBERS SLIDE}

International student numbers are already sliding in vocational colleges and the specialist English-language institutions. In July 2010, the total number of new (commencing) international students in all sectors was down 22 percent on July 2009. New students from India dropped by 80 percent, and from Thailand, Vietnam, and Hong Kong by 20 percent. Data on new visa applications suggest another fall of almost 20 percent in early 2011 and confirm that the universities are affected. The decline has spread to Australia's main source country-China.

Why has this happened? Both demand for and the supply of Australian education are trending downwards. The main driver has been changes on the 
supply side. It is sad to report that Australia has become less welcoming to international students.

The first sign of trouble appeared two years ago. When a pattern of violent assaults affecting South Asian students hit the front pages of newspapers in both Australia and India, the Australian authorities were slow to respond and received a hammering in the media in India. Then, the Australian government cracked down on migration "scams" perpetuated by some private training colleges in collaboration with education agents in India. Australian education's recruiting power in India slid further.

\section{MigRATION RESISTANCE}

Yet, the main reason why the international education "industry" is in trouble is migration resistance in the Australian electorate, which has grown in recent years.

Australia is like the United States, Canada, and parts of South America-in that it is a high-migration nation. However, political attitudes to migration fluctuate. Currently, opinion polls are showing that almost four Australians in five say that Australia receives "too many" migrants. Resistance to migration is highest in the eastern cities of Brisbane and Sydney, where years of underinvestment in infrastructure mean that transport, power, water, and other services are under strain.

In the recent Australian federal election both parties realized the election would be decided in Brisbane and Sydney. The opposition Liberal-National parties openly pledged to cut net overseas migration by over 40 percent. But 
changes already instigated by the Labor government are in the process of achieving that target.

The number of international students on temporary visas is almost double that of permanent migrants. Any substantial downsizing of net overseas migration can only be achieved through major reductions in the number of visas issued to international students.

Government is reducing both the number of incoming students and of graduates who become permanent migrants. Precise figures are difficult to obtain, but it appears that about 40 percent of all international student graduates seek migration status.

The immigration department has created tougher conditions for student visas. Applications face longer delays, some well over three months, and many go elsewhere. In addition, it is now harder for graduates to obtain permanent residence because of work experience and language tests. The skilled migrant intake has been reduced. The immigration minister has the power to apply a discriminatory cap on the number of migrants from particular countries. All these changes have sent out the message that students and migrants are less welcome in Australia. This in turn is driving down demand, as shown by the fall in visa applications.

Australia's capital Canberra is aware that the change in government migration policy has severe consequences for this industry. But the protracted postelection delay before formation of a new government has compounded the problem. No one is taking policy responsibility.

Estimates of the likely downturn in the numbers of international students in Australia-if policy does not change-vary from 40 to 60 percent. Part of 
Australia's share of the global student market will be absorbed by Englishlanguage competitors. In the United Kingdom and United States universities are under pressure to expand the number of international students because of severe cuts in government funding. 